\title{
1950 öncesi Sürrealizm ve Müzik İlişkisi: Anlaşmazlıklar ve Yakınlaşmalar*
}

\section{Surrealism and Music Relations Before 1950: Conflicts and Convergences}

\author{
Bilge Evrim Aydoğan ${ }^{1}$ (ic
}

*Bu çalısma "The Three Paintings from Salvador Dali: Relationship Between Music and Visual Arts in the Context of IIlhan Usmanbaş" adlı doktora tezinden türetilmişstir.

'Sorumlu yazar/Corresponding author: Bilge Evrim Aydoğan (Doktora Öğrencisi), Istanbul Teknik Üniversitesi, Sanat Tarihi Bölümü, Istanbul, Türkiye

E-posta: bilgeaydogan@gmail.com ORCID: 0000-0003-3746-4266

Başvuru/Submitted: 20.01 .2020 Revizyon Talebi/Revision Requested: 07.04.2020

Son Revizyon/Last Revision Received: 18.04.2020

\section{öz}

1924 yılında şiirde devrimsel bir hareket olarak ortaya çıkan Sürrealizm, kısa sürede ilgisini resim, heykel, fotoğraf, mimari ve sinema gibi farklı disiplinlere yöneltse de temellerini dayandırdığı Sembolizm ve Dada'nın aksine müzikle arasına bilinçli bir mesafe koymuştur. Ancak bu duruş, 1930'ların sonuna doğru akımda yaşanan çözülme ve ardından Breton da dahil olmak üzere Salvador Dali, Max Ernst, André Masson gibi sanatçıların savaş nedeniyle Amerika'daki geçirdiği sürgün yıllarında yön değiştirmiş̧tir. 1950 sonrası, Sürrealizm ile müzik arasındaki ilişkinin giderek belirginleşmeye başladığı dönemdir. Özellikle caz müziği ve müzikteki post-modern uygulamalar, sürrealist düşüncenin müzikteki yansıması olarak değerlendirilmektedir. Bu makale, hakkında az sayıda çalışma bulunan 1950 öncesine, Sürrealizm ile müzik ilişkisinin daha belirsiz kaldığı bir döneme odaklanmaktadır. Öncelikle sürrealist hareketin müziğe karşı negatif duruşunun nedenleri tartışılmış; bunun karşısında kendini sürrealist düşünceye yakın hisseden ve müziğinde sürrealist unsurlar barındıran bestecilere yer verilmiştir. Çalışmanın son bölümünde ise dizisel müzik ve raslamsallığa giden yolda müzikteki gelişmelerin sürrealist düşünceye hangi noktalarda yakınlaşı̆̆ı̆ IIhan Usmanbaş'ın Dali'den Üç Resim (1952-1955) örneği üzerinden incelenmiştir.

Anahtar kelimeler: Sürrealizm, Dizisel müzik, Illhan Usmanbaş, Dali'den Üç Resim

\section{ABSTRACT}

The Surrealist movement, which emerged as a revolutionary movement in poetry in 1924, quickly moved towards various other disciplines such as painting, sculpture, photography, architecture and cinema, but unlike Symbolism and Dada, the movement exhibits a conscious distance from music. However, this stance went through a change during the dissolution period of the movement in the late 1930s, and later in the exile years of artists such as Breton, Salvador Dali, Max Ernst, and André Masson in America. After 1950, the relationship between surrealism and music became more apparent. Developments in jazz music and post-modern practices have particularly been evaluated as the reflection of surrealist thought. The purpose of this study is to explore the relationship between music and surrealism by focusing on the pre-1950s period where this relation remains more unclear. The first part of the study discusses the reasons 
for the surrealist movement's negative attitude towards music, and furthermore gives examples from the composers who had felt close to surrealist thinking and whose music contains surrealist elements. In the final part of this study, we aim to examine the points where surrealist thinking meets with development of music on the path leading to serial and aleatoric music through the example of İlhan Usmanbaş's musical piece Three Painting from Dali (1952).

Keywords: Surrealism, Serial music, Ilhan Usmanbaş, Three Paintings from Dali 


\section{Giriş}

Sürrealizm, günümüz sanat pratikleri üzerinde etkili akımlardan biridir. Dada' dan devraldığı yabancılaşma, devrimci hareket, etnografik bakış ve gündelik yaşamın yüceltilmesi gibi kavramları yüzyıl düşüncesine aşılamış; iki dünya savaşı arasında varlık göstermesi ve uluslararası örgütlü yapısı dolayısıyla da savaş öncesi Avrupa'da yaşanan gelişmelerin savaş sonrasına aktarılmasında ayrıcalıklı bir rol almıştır. Bir başka değişle Sürrealizm, modernizmi post-modernizme bağlayan köprü görevi görmüştür.

Sürrealist hareketin müzikle ilişkisi İkinci Dünya Savaşı sonrası belirginleşmeye başlamıştır. Caz müziğinin yeniden keşfi ve özellikle serbest doğaçlamanın yükselişi, Sürrealizmin müzikteki karşılığı olarak görülmüsşür. ${ }^{1}$ Bununla karşısında, Avrupa'daki sürrealistlerin de Charles Parker (1920-1955), Dizzy Gillespie (1917-1993), Bud Powell (1924-1966) ve Theloniuos Monk (1917-1982) gibi müzisyenlerin albümlerini takip ettikleri; hatta müzik konusunda önyargılara sahip André Breton'un (1896-1966) dahi Amerika'daki sürgün yıllarında caz konserine gittiği bilinmektedir. ${ }^{2}$ Romanyalı sürrealist sanatçı Victor Brauner'ın (1903-1966) Thelonious Monk Portresi (F.1) ve Claude Tarnaud'nn (1922-1991) Düşünceli Form (La Forme Léfléchie, 1953) kitabında yer alan 'Miles Davis', 'Theloniuos Monk’ ve 'Max Roach' başlıklı şiirleri de sürrealistlerin bu dönemde caz üzerinden müziğe yakınlaşmasının örnekleri arasında değerlendirilmektedir. ${ }^{3}$

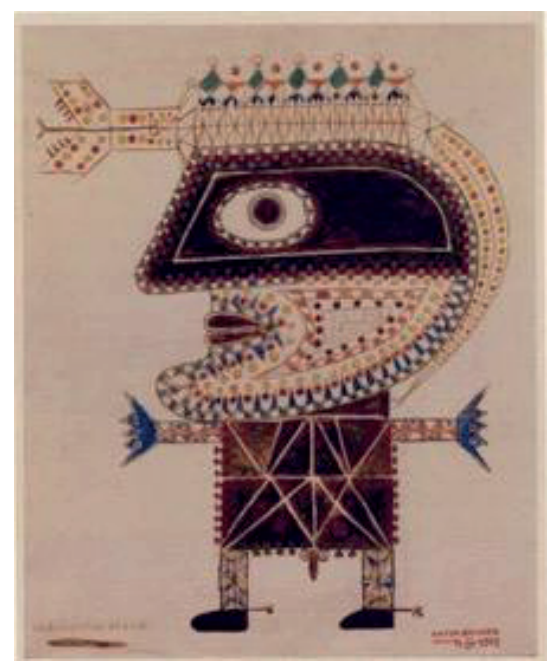

F. 1: Victor Brauner, Thelonious Monk'un Portresi, 17 Ağustos 1948 imzalı (Steve Lacy, "More Monk" Soul Note album Kapağ1, 1991)

1 Michael Szekely, "Jazz Naked Fire Gesture: Improvisation as Surrealism”, Papers of Surrealism, Issue:9, Summer 2011.

2 André Breton, "Silence is Golden" giriş bölümü, What is Surrealism? Selected Writings, Ed. Franklin Rosemont, Pathfinder Press, 2006, s. 348.

3 Paul Garon, Blues and the Poetic Spirit, City Lights Publishers, 1996, s. 215. 
Caz dışında Sürrealizmin müzik ile arasındaki bir diğer yakınlık çağdaş müzikte uygulanan tekniklerle gündeme gelmektedir. LeBaron, Sürrealizmin Postmodern Müzikteki Yansımaları (Reflections of Surrealism in Postmodern Musics 2002) makalesinde, otomatizm ile serbest doğaçlamayı; kolaj tekniğiyle ise 'eşzamanlılık', 'çoğulluk' ve 'alıntılama' gibi uygulamaları karşılaştırarak, akımın gerçek etkisinin post-modern müzik ile ortaya çıktığını öne sürmektedir. ${ }^{4}$ Benzer düşünceye Jonathan D. Kramer de sahiptir. Sürrealizmin, post-modernizm gibi bir üsluptan daha fazlasını ifade ettiğini belirten Kramer; her ikisinin de bir yaklaşım biçimi, dünya hakkında bir düşünce tarzı, bir us hali olduğunu belirttiği yazısında sürrealist teorilerin günümüz post-modern müziğini anlamaya imkan sağlayan değerli öğrenimler olduğuna işaret etmektedir. ${ }^{5}$

Ancak 1950 sonrasının aksine, 1950 öncesi Sürrealizm ve müzik ilişkisine odaklanan az sayıda çalışma bulunmaktadır. Bu çalışmalar arasında konuya müzik taraftan bakarak geniş bir zamansal çerçevede inceleyen Nicolas Slonimsky’nin Sürrealizm ve Müzik (Surrealism and Music, 1966) makalesidir. Sürrealist yaklaşımın müzikteki karşılığını salon müziğine ve virtüözlüğe adanmış tonal müziğe bir tepki olarak tanımlayan Slonimsky, içinde sürrealisttik özellikler taşıyan Rusya ve Avrupa'dan avangard müzik örneklerini sıraladığı çalışmasında, elektronik müziğin öncüsü Edgard Varése'den (1883-1965) hareketle John Cage'e (19121992) uzanan ve oradan da grafik notasyona ulaşan müziğin serüvenini, sürrealist düşüncenin müzikteki yansımaları olarak değerlendirmektedir. Slonimsky, kolaj ve montaj gibi sürrealist tekniklerin müzikal karşılığının ise, 1940’ların sonuna doğru Pierre Schaeffer (1910-1995) ve Pierre Henry'nin (1927-2017) 'musique concrete'í ile ortaya çıktığını ileri sürmektedir.?

Elektro-akustik denemelerinin sürrealist ruha daha yakın olduğunu düşünen bir başka isim Jacqueline Chenieux-Gendron'dur. Ancak Chenieux-Gendron da akımın müzikle ilişkisine yalnızca birkaç sayfa ayırdığı kitabında, Sürrealizmin müzik ile buluşabilmesi için uygun ortamın tarihsel perspektifte geri alınmaz biçimde kaçırıldığını ileri sürmektedir. ${ }^{8}$ Daniel Albright ise Sürrealizm ve müzik ilişkisine besteci, eleştirmen, şair ve düşünürlerin yazılarını bir araya getirdiği Modernizm ve Müzik: Bir Kaynak Seçkisi (Modernism and Music: An Anthology of Sources, 2004) kitabinda yer vermektedir. Darius Milhaud (1892-1974), Igor Stravinsky (1882-1971), Georges Auric (1899-1983), Arthur Honegger (1892-1955) ve Francis

4 Anne LeBaron, "Reflections of Surrealism in Postmodern Musics", Postmodern Music / Postmodern Thought, ed. Judy Lochhead, Joseph Auner, Routledge (Studies in Contemporary Music Andculture), 2002, ss. 27-75).

5 Jonathan Kramer, Postmodern Music Postmodern Listening, ed. Robert Carl, Bloomsbury Academic, 2016, s. 178.

6 Pierre Schaeffer ve Pierre Henry öncülüğünde ses bandı üzerinde gerçekleştirilen ilk elektronik müzik denemeler 'musique concrete' olarak adlandır1lır. 'Elektronische Musik' ise Pierre Boulez (1925-2016) ve Karlheinz Stockhausen'ın (1928-2007) Köln Radyo’sundaki çalışmalarına verilen isimdir. Musique Concrete ile Elektronische Musik'in ortak yanı, besteciye sağladığı geniş ses olanağıdır. Aralarındaki ayırım ise kullandıkları sesin kaynağında ortaya çıkmaktadır. Musique Concrete, doğal seslerin kayıtlarını kullanır. Bundan dolayı 'somut' müzik olarak da adlandırılmaktadır. Elektronische Musik'de ise sesler, elektronik ortamda üretilmektedir (İlhan Mimaroğlu, Elektronik Müzik, Pan Yayınları, 1991. ss.23-24).

7 Nicolas Slonimsky, "Surrealism and Music", Writings on Music: Music of the Modern Era, ed. Electra Slonimsky Yourke, Routledge, 2005, s.138.

8 Jacqueline Chenieux-Gendron, Surrealism, trans. Vivian Folkenflik, Columbia University Press, 1990 , s. 168. 
Poulenc (1899-1963) gibi müziğinde sürrealist nitelikler taşıyan bestecilerin örneklerine başvuran Albright, müziğin Dişavurumculuk, Neoklasisizm ve Yeni Nesnelcilik gibi modern sanat akımları içinde önemli bir rolü olduğunu, ancak buna karşılık sürrealistler tarafindan gereğinden az değer gördüğünü belirtmektedir. Albright, bunun nedenini, akımın sanatçılarının müzikle ilgili az şey bilmeye meyilli olmalarıyla ilişkilendirmektedir.?

1950 öncesi Sürrealist hareketin müzik hakkında genel bir ortak söyleme sahip olmamas1, grubun üyesi olan ya da bir şekilde sürrealist hareket ile temas eden sanatçıların çeşitliliği ile açıklanabilir. Ancak akımın müzikle ilişkisindeki bu belirsizlik en çok, hareketin kurucusu ve teorisyeni André Breton'un müziğe karşı takındığı negatif tavırla ilişkilendirilmektedir. Nitekim, her konuda düşüncelerini çekinmeden sunan sürrealistlerin yazılarında müziğe çok az yer vermeleri, Breton'un yaklaşımının akımın diğer üyeleri tarafından benimsendiğinin bir göstergesi olduğu düşünülebilir. Satır aralarında ya da yeri geldiğinde verdikleri örnekler dışında, sanki söz birliği etmişler gibi müzik için ayrı bir başlık açmamış olmaları, akımın müzikle ilişkisini muğlak bırakan bir unsurdur. Yine de sürrealistlerin müzik hakkında yazdığ iki önemli metin bulunmaktadır.

Bunların ilki Breton'un etkili olan düşüncelerine rağmen müziğe yakınlığıyla bilinen Belçikalı grubun üyesi olan Paul Nougé'un Müzik Tehlikelidir (Music is Dangerous) adlı metnidir. ${ }^{10}$ Nougé, 1929 yılında René Magritte (1898-1967) ve André Souris (1899-1970) ile birlikte Belçika'nın Charleroi kentinde düzenledikleri sergi ve konser etkinliğinde gerçekleştirdiği konferansta, müzikten kaçamayacaklarını dile getirmektedir. Müziğin insan üzerindeki psikolojik etkilerinden ve dinleyici algısında yarattığ 1 tecrübelerden bahseden Nougé, müziğin dil ve anlam ile ilişkisi üzerine de değerlendirmelerde bulunmaktadır. ${ }^{11}$

Diğer metin Breton’un 1946 yılında kaleme aldığg Sükut Altındır (Silence is Golden) makalesidir. Arnold Schoenberg'in (1874-1951) yetmişinci doğum günü onuruna yazılan yazılarla birlikte Modern Music dergisinde yayınlanan metinde, daha önce müzikle arasına net bir çizgi koyan Breton'un düşüncelerini gözden geçirdiği görülmektedir. Yazısında bir yandan müziğe karşı duyduğu uzaklığın haklı nedenlerini açıklayan Breton, bir yandan da müzik ile Sürrealizm arasındaki husumetin aşılması gerektiğini ve bunun da her iki sanatın prensiplerinin yenilenmesiyle gerçekleşebileceğini belirtmektedir. ${ }^{12}$ Breton'un müzik üzerine düşüncelerini yeniden değerlendirdiği bu metin, akımın müzikle ilişkisinde dönüm noktasına işaret etmektedir.

9 Daniel Albright, Modernism and Music: An Anthology of Sources, University of Chicago Press, 2004, s.309.

10 Nouge'un metni, sürrealistlerin müzik üzerine yazdığı ilk metin olsa da basılı bir yayına dönüşmesi Breton'un Sükut Altındır (Silence is Golden, 1946) makalesinden sonra gerçekleşmiştir. Metin ilk kez, 1946 yılında Charlreroi Konferansı başlıklı bir kitapçıkta yayınlanmış; ingilizce çevirisi ise kısmen kısaltılmış haliyle Amerika'da View dergisinin 1946 Aralık ve 1947 Bahar sayılarında yer almıştır.

11 Paul Nougé, "Music is Dangerous", trans: Felix Giovanelli, View Magazine: Surrealism in Belgium, vol. VII, No:2, December 1946, ss.15-21.

12 André Breton, "Silence is Golden" (1946), What is Surrealism? Selected Writings, ed. Franklin Rosemont, Pathfinder Press, 2006, s. 350. 


\section{Sürrealizm ve Müzik Arasındaki Estetik, Teknik ve İdeolojik Anlaşmazlıklar}

1920 'lerde Paris Les Six grubunun üyesi olan ve sürrealist hareketle yakından ilgilenen besteci Francis Poulenc (1889-1963), şair Paul Eluard (1895-1952) dışında tüm sürrealistlerin müzikal olarak cahil olduğundan yakınmaktadır. ${ }^{13}$ LeBaron ise Sürrealizm ile müzik arasındaki kopukluğun, kıskançlık ve yanlış anlaşılmaların bir sonucu olduğunu ve bunun da müziği, tüm sanatlar içinde 'en kafa karıştırıcı form' olarak tanımayan Breton'un akım üzerinde etkili olan düşünceleriyle açıklamaktadır. ${ }^{14}$ Breton'un sürrealist düşünceyi etkileyen negatif tavrını estetik, teknik ve ideolojik olmak üzere üç başlıkta incelemek mümkündür.

\section{Estetik Anlaşmazlık}

Sürrealistlerin imgelem dünyası, insanı çevreleyen dış dünyadan bağımsız değildir. Aksine bu akımın sanatçıları, görünür olan dışsal gerçeklik ile zihnin düş gücü arasında bağ kurmaya çalışmışlardır. Buna göre soyut ifade, imgelerle dolu bu iki dünya arasındaki ilişkiyi kurmada yetersiz kalmaktadır. Dolayısıyla sürrealistler, soyut resim gibi yine soyut bir sanat formu olarak gördükleri müziği de aşağı görmektedir. Akımın soyuta karşıtı tutumun nasıl kabul gördüğü, Salvador Dali’nin (1904-1989) sürrealist gruba katıldığı ilk yıllardaki dönüşümü üzerinden izlenebilir.

Dali, Breton'un Sürrealism ve Resim (Le Surréalisme et la peinture, 1928) makalesinden sadece birkaç ay sonra yazdı̆̆ı̆ Resim 'de Yeni Sinırlar (Nous Limits de la Pintura, 1928) başlıklı yazısının ilk basımında, kendini çoktan Kübizm'in sınırlarını aşmaya girişmiş ve Sürrealizm ile soyut sanat arasında arabuluculuk yapan bir yerde konumlandırmaktadır. ${ }^{15}$ Bu yazının en dikkat çekici bölümü, Dali'nin düşüncelerini çoğu kez müzikal metaforlarla açıklayan Pürist sanatçı Amédéé Ozenfant'ın (1886-1966) uzun bir alıntısına yer vermesidir. Bu alıntıda Ozenfant, resim pratiğini piyanonun renk ve biçimden oluşan sistematik kuruluşuna benzetmektedir. Ona göre; sonsuz olasılıklar içinden gerekli ve yeterli olan seslerin seçildiği piyano gibi, resim de temel renk ve formlardan oluşan bir çeşit klavye işlevi görmelidir.

Resmin sınırlarını müzikal metaforlarla desteklemeyi tercih eden Dali' deki değişim, yazının sadece birkaç ay sonra yayınlanan ikinci baskısında ortaya çıkmaktadır. Dali bu kez, Ozenfant'ın purist yaklaşımının tam karşısında bir tavır sergilemek gerektiğini öne sürerek yazısına başlamışıır. ${ }^{16}$ Joan Miro (1893-1983), Max Ernst (1891-1976) ve Jean (Hans) Arp'dan (1886-1966) örneklere yer veren Dali'deki bu hızlı değişim, Breton etkisinin ve sürrealist ilkelere adapte olma sürecinin bir göstergesidir. $\mathrm{O}$ artık, gerçeklik algııı ve psikolojik etkenler arasındaki ilişkiyi araşııran bir sanatın savunucusu olmuştur. Nitekim bir başka yazısında "içgüdüsel ve psişik duyusal tepkilerin, müzikal türde soyutlamanın kuralcı değerlerinin yerine geçeceğini” iddia edecektir. ${ }^{17}$

13 Albright, a.g.e., 2004, s.309.

14 LeBaron, a.g.e., 2002, s. 30.

15 Salvador Dali, "New Limits of Painting" Collected Writings of Salvador Dali, ed. Haim Finkelstein, Cambridge University Press, 1998, s.73.

16 Dali, a.g.e., 1998 , s. 85.

17 Salvador Dali, “The Sanitary Goat", Collected Writings of Salvador Dali, ed. Haim Finkelstein, Cambridge University Press, 1998, 226. 
Dali, sürrealist düşünceyi inceleme ve kendi sanatına adapte etme sürecinde fotoğraf ve sinemadan da yararlanmıştır. Ona göre gerçeklik ile gerçeküstü olgular arasındaki geçişkenliği fotoğraftan daha iyi sunabilecek başka bir medyum yoktur; kamera ise gizli kalmış tinsel katmanlar arasındaki ilişkiyi görmek için en uygun araçtır. ${ }^{18}$ Luis Buñuel (1900-1983) ile birlikte gerçekleştirdikleri Endülüs Köpeği (Un Chien Andalou, 1929) filmi bu ilginin bir ürünüdür. Absürt ve rahatsız edici görüntüler ile laytmotif öğelerin yer aldığı filmde, Richard Wagner'in (1813-1883) Tristan ve Isolde'sinden bölümler ve bir tango müziği kullanılmıştır. Birbiri içine giren müzikteki bu ikili durum, ciddiyet ve alaycılık arasında hem bir karşıtlık hem de absürt bir diyalog yaratmaktadır. Endülüs Köpeği'nde dikkat çeken bir başka müzikal unsur, gerçek hayatta görmeye alışkın olmadığımız biçimde sunulan piyanodur (F.2). Filmde iki rahip tarafından iplerle çekilen piyanonun içine ölü eşek bedenleri yerleştirilmiştir. Finkelstein, bu “tuhaf sırtlanma işini” Buñuel'in din karşıtı söyleminin bir parçası olarak görmektedir. ${ }^{19}$ Douglas Kahn ise daha biçimsel yaklaşarak piyanonun tuşları ile ölü hayvanların dişleri arasındaki görsel oyunu Dali'nin müziği aşağı gören algısıyla ilişkilendirmektedir. ${ }^{20}$

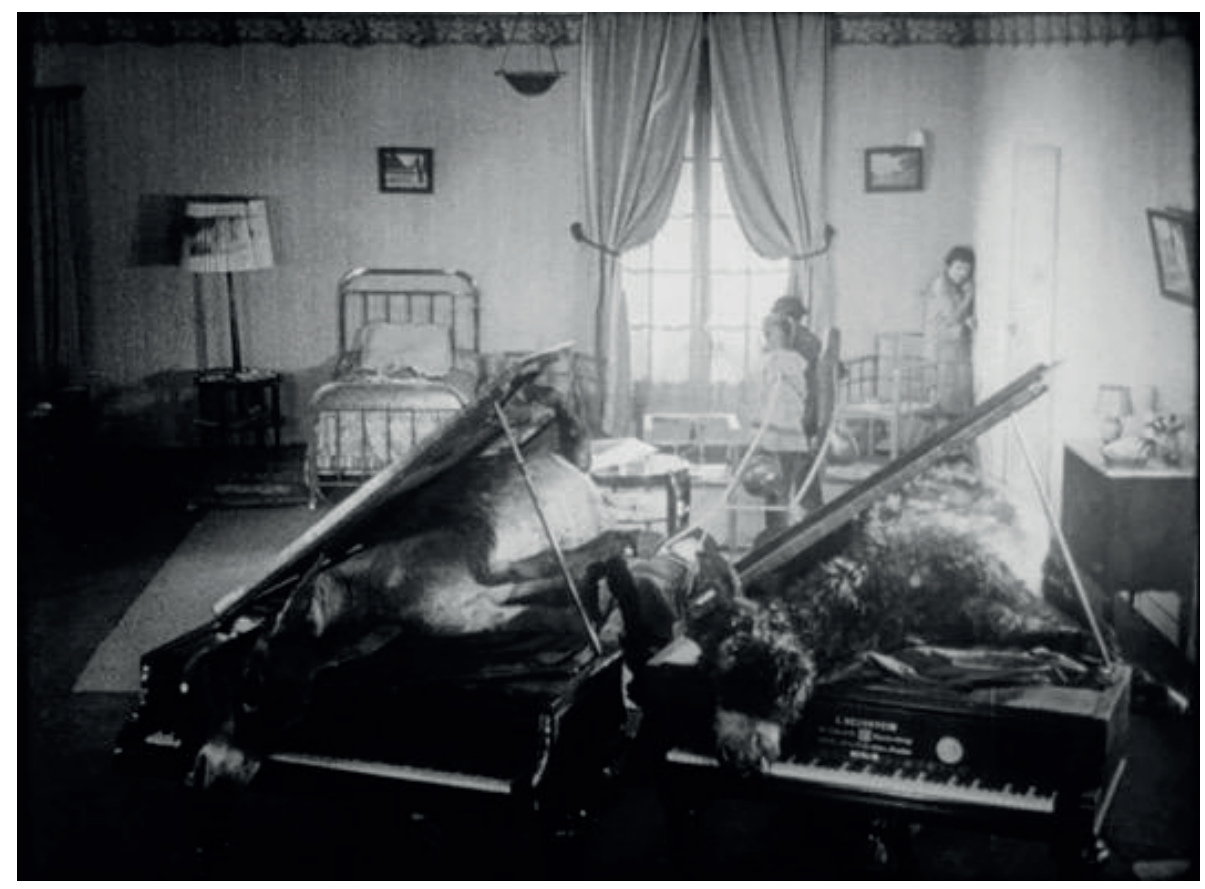

F. 2: Dali ve Buñuel, "Un Chien Andalou” (Bir Endülüs Köpeği) piyano sahnesi, 1929. (erişim tarihi: 12.01.2020 https://theculturetrip.com/europe/spain/articles/a-visualretrospective-of-luis-bunuels-filmography/)

18 Salvador Dali, “Art Film, Antiartistic Film” (1927), Collected Writings of Salvador Dali, ed. Haim Finkelstein, Cambridge University Press, 1998, ss.53-57.

19 (Ed.) Finkelstein, Haim, Collected Writings of Salvador Dali, Cambridge University Press, 1998, s. 120.

20 Douglas Kahn, Noise Water Meat: A History of Sound in the Arts, MIT Press, 2001, s. 34. 
Nitekim Dali, filmden birkaç yıl sonra yayınladığı Sinemanın Kısa Eleştirel Tarihi (Abrégé d'une Historie Critique du Cinéma) yazısında, görüntülerdeki akışın ritimsel özelliğinden dolayı sinemanın da soyut bir sanat formu olduğunu iddia edecektir. ${ }^{21}$ Ona göre ritim, uyumun bir sonucudur; uyum ise soyuttur ve şiirin maddesel özelliğine taban tabana zıttır. Dali, Breton'un sıklıkla vurguladığı hiyerarşik sanat düzenine referans verdiği yazısında, sinema hakkındaki düşüncelerini, müziğe de pay çıkartacak şekilde şu sözlerle ifade etmektedir:

"Sinema, yaygın düşüncenin aksine düşüncenin gerçek işleyişinin ifadesi olarak, yazı, resim, heykel ve mimariden çok daha zayıf ve sınırlıdır. Bilindiği üzere tinsel değeri pratikte sıfır olan müzik olmadıkça onun altında neredeyse hiçbir şey yoktur. Sinema, özünde olayların ve soyutlamanın yanındadır ve tanım gereği somut olanın yani şiirin tam karşısındadır." 22

Breton'un hiyerarşik sanat anlayışına göre şiir, Romantizm'le birlikte özgürlüğe ilk adım atan ve tüm sanatların önüne geçerek onları derinden etkileyen sanat formudur. Onun ardından dış dünyada görüneni resmetmeyi bırakıp, düş gücünü kullanarak gerçeklik ile bilinçdışı arasında bağ kurmayı başaran resim; daha sonra şiirin sunduğu yönde biçim alan heykel ve mimari, en sonda ise müzik gelmektedir. ${ }^{23}$ Sanatlar arasındaki bu hiyerarşi, algılar arasında da bir sıralamaya işaret etmektedir. Buna göre görmek, diğer algısal süreçler içinde en önemli olandır. Nitekim gözlerinin kapalı olduğu rüya halinde ortaya çıkan imgeler görmenin değeriyle anlam kazanmaktadır.

Ancak Breton’un aksine Belçikalı sürrealist Nougé, müziğin dış dünyadan kopuk olmadığını düşünmektedir. Ona göre müziğin de görünür bir dünyası vardır ve bu dünya tıpkı rüyalar gibi bilinçle birlikte ortaya çıkmaktadır. Bunun dışında müzikteki bir başka görsel değer, dinleyicinin izleyici rolüne geçmesiyle gerçekleşmektedir. Sadece icracının ya da sahnedeki performansın izlenmesinden ibaret olmayan bu eylem, Nougé'a göre sürrealistlerin aşina olduğu bir pratiktir. İzleyiciyi aynı zamanda performansa iştirak eden bir konuma getirmektedir ve tıpkı aynadaki yansımalar gibi insana kendini, diğer izleyicileri ve mekanı gözlemleme deneyimi sunmaktadır. ${ }^{24}$ Dolayısıyla bakma eylemi müziğin varlığı karşısında da tecrübe edilebilmektedir.

Öte yandan Nougé, müziğin elle tutulur somut bir dünyaya ait olduğunu düşünmektedir. Sonuçta müzik de gözle görünen, elle tutulan formaların dünyasına ait kavramlarla açıklanmaktadır. Müziğin iki temel unsuru olan form ve hareketi, yaşadığımız tecrübelerle tanımladığımıza, algıladığımıza ve hatta taklit ettiğimize dikkat çeken Nougé, müziğin de aynı düzende bir etki yarattığını iddia etmektedir. Tıpkı herhangi bir fiziksel nesne ile kurduğumuz ilişkideki gibi, müzik karşısında da yine onun önerdiği form ve hareket doğrultusunda davranışlarımızı biçimlendirmekte olduğumuzu belirtmektedir. ${ }^{25}$

21 Salvador Dali, “The Short Critical History of Cinema” (Abrégé d'une Historie Critique du Cinéma, 1932) Collected Writings of Salvador Dali, ed. Haim Finkelstein, Cambridge University Press, 1998, s.137.

22 Dali, a.g.e., 1998, s. 137

23 Ali Artun, Nur Altınyıldız (ed), Sürrealizm / Mimarlık, İletişim Yayınları, 2014, s. 23.

24 Paul Nougé, 1946, a.g.e., ss. 15-21

25 Paul Nougé, 1946, a.g.e., ss. 15-21 


\section{Teknik Anlaşmazlık}

Sürrealistler, psikanalistlerin uyguladığı serbest çağrışım tekniğinden ilham aldıkları ve devrim niteliğinde bir keşif olarak değerlendirilen otomatizmi yalnızca teknik bir uygulama değil, aynı zamanda sürrealist idealin birebir karşıllı̆̆ olarak görmüşlerdir. Breton, Sürrealizmi "Kişinin, sözlü, yazılı veya başka bir yolla, düşüncenin gerçek işleyişini ifade etmeyi denediği, en saf halindeki psişik otomatizm" ${ }^{26}$ olarak tanımladığ 1 ilk manifestoda resim sanatından hiç bahsetmemiştir. Hatta yayınlanmasının hemen ardından Max Morise (1900-1973) ve Pierre Naville (1903-1993) gibi yazarlar, ressamların yeteneklerini denetimli kullanmalarından dolay1 resim sanatının sürrealist olamayacağını iddia etmişlerdir. ${ }^{27}$ Başlangıçta resme karşı duydukları bu şüphe, müzik söz konusu olduğunda daha keskin ve net olmuştur. Onlara göre müzik, gerek besteleme süreci gerekse de pratik edilmesinde, otomatizmi teknik olarak uygulayacak yeterli formasyona sahip değildir.

Ancak Amerikalı besteci ve eleştirmen Virgil Thomson (1896-1989), otomatizmin müzik için yeni bir kavram olmadığını ileri sürmektedir. Breton'un Sükut Altındır makalesine cevaben yazdığı yazısında, bestecilerin ilham kaynağının bilinçaltı olduğunu belirterek çağrışımlarla biçim alan müziğin yaratım sürecini otomatizmle ilişkilendirmektedir. Buradan hareketle Thomson, bir doğaçlama ustası olarak da bilinen Bach'a gönderme yaparak bu tekniğin müzikte yüzyıllardır pratik edildiğini iddia etmektedir. ${ }^{28}$

Diğer taraftan bir keşif aracı olarak görülen otomatizmin, 1930'ların sonlarına doğru artık bir keşfedilemeyene dönüştüğü görülür. Zihnin rüya haline geçmesinde bir anahtar olan bu teknik, uygulamadaki zorluklarından dolayı tıkanan bir noktaya gelmiştir. Bu tıkanıklık aynı zamanda, akımda yaşanan çözülmenin de bir işareti olarak değerlendirilmiştir. ${ }^{29}$ Nitekim Breton'un dahi otomatizme yüklediği anlam değişmeye başlamıştır. 1940'ların başlarında kaleme aldığı yazısında, resmin ya da şiirin kompozisyon kuruluşunda belli oranda bir ön tasarımın mümkün olduğunu kabul etmektedir. ${ }^{30}$

Otomatizmin tıkandığı noktada sürrealist sanatçıların kendine özgü yöntemlerle öne çıkmaya başladığı görülür. Max Ernst, yıllarca uyguladığı 'frotaj' tekniğinden sonra 1930'ların sonlarına doğru önce 'decalcomania' ve ardından 'oscillation' tekniklerini geliştirmiştir. ${ }^{31}$ Dali ise otomatizmdeki tıkanığa bir çözüm için, ‘paranoyak kritik’ yöntemi önermektedir.

26 André Breton, Sürrealist Manifestolar, Altıkırkbeş Yayın, 2009, s.31.

27 Artun, Altınyıldız (ed), a.g.e., 2014, s. 13.

28 LeBaron, a.g.e., 2002, s. 37.

29 Laurent Jenny, Thomas Trezise, "From Breton to Dali: Adventures of Automatism, October, MIT Press, , Vol. 51 (Winter, 1989), pp. 105-114.

30 Breton, André, "Genesis and Perspective of Surrealism in the Plastic Art" (1942), What is Surrealism? Selected Writings, ed. Franklin Rosemont, Pathfinder Press, 2006, s.296.

31 Decalcomania, tuval üzerine akıtılan boyanın kağıt ve cam malzemelerle bastırılarak çeşitli yüzey yapılarının elde edildiği bir tekniktir. Elde edilen bu izler, daha sonra fırça yardımıyla mercan ya da su yosununu andıran formlara dönüştürmek için kullanır. 'Oscillation' tekniğini ise Amerika'daki sürgün yıllarında geliştiren Ernst, bu teknikte boyayı, delik bir teneke kutudan bedenin yaptığı salınımlarla birlikte tuval üzerine akıtılır. Böylece ortaya çıkan çizgi ve formlar, Ernst'in resimsel düzlemin için bir başlangıç noktası oluşturmuş olur. 
Yönteminin temellerini 1930'ların başında atan Dali, Sürrealist Deneylerde Ortaya Çıkan Nesne (The Object as Revealed in Surrealist Experiment, 1932) başlıklı yazısında Sürrealizmin ilk evresinin tamamlandığını ileri sürmektedir. Bu ilk evreyi otomatizm ve rüyaların dahil olduğu gece kuşağıyla ilişkilendiren Dali, ikinci evrenin ise gündelik yaşamın gerçekliği ile daha yoğun ilişkide olduğunu ve bu evreye geçen araştırmacıların da otomatizmin aksine, sürrealist deneylere müdahale etme arzusuna sahip olduklarını belirtmektedir. ${ }^{32}$

Dali'nin yöntemi, zaman içinde pasif kalan otomatizme karşı aktif ve düzenli bir dönüşüm önermektedir. Resimlerinde sıkça rastlanan imgenin çoklu biçimi, bu gözlemin en belirgin uygulamasıdır. Kimi zaman ikili, üçlü ya da daha fazla olacak şekilde de çoğalabilen imgeler, Dali'nin tabiriyle kişiye gerçekliğin ve bu gerçeklik içinde algılanan objelerin birbiri ardına gelen sürekli değişimini görebileceği bir deneyim sunmaktadır (Fig.3). Dali’nin imgelerindeki benzer dönüştürmeyi, Pierre Schaeffer'in 'musique concrete' denemelerinde kullandığg ses nesnelerinde bulmak mümkündür. Schaeffer, orijinal seslerin kimi zaman tanınmayacak şekilde düzenlendiği bu müzikte çanın bir insan sesine, insan sesinin bir kemana, kemanın ise bir deniz kuşuna dönüşebildiğini belirtmektedir. ${ }^{33}$

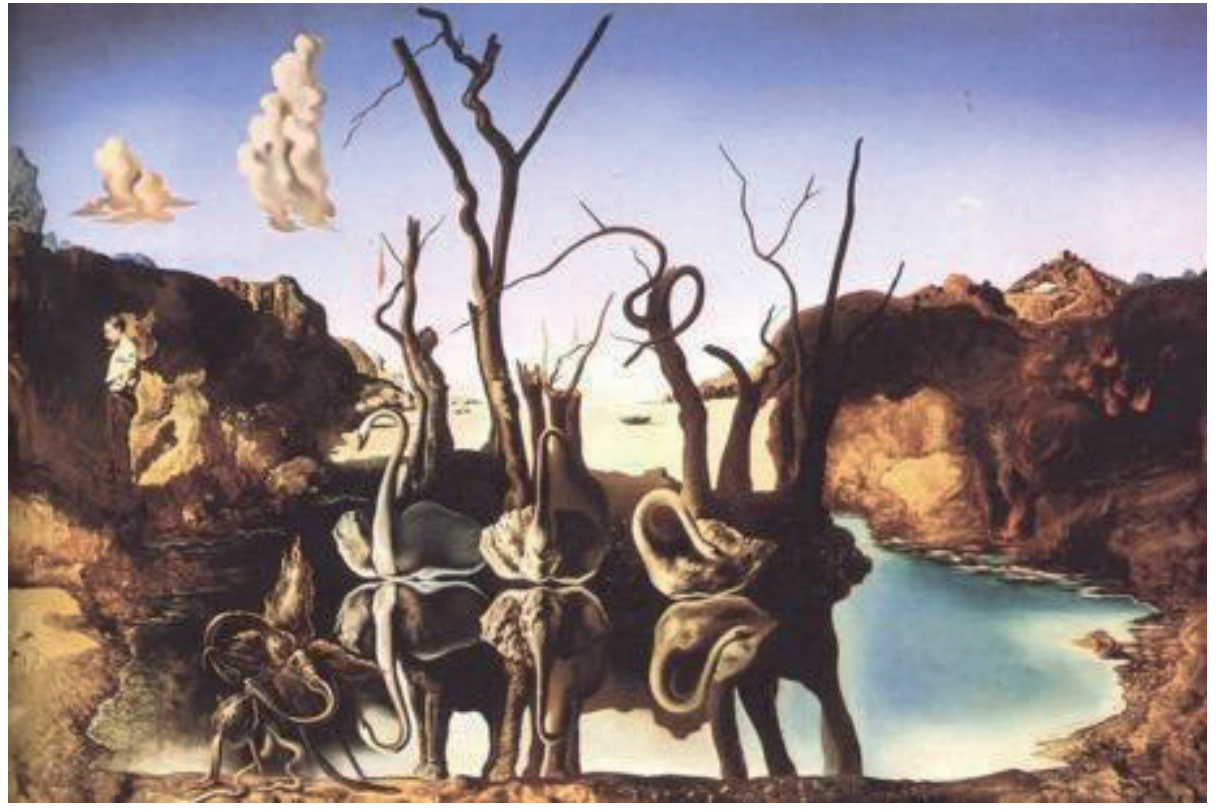

F. 3: Salvador Dali, Swans Reflecting Elephants, 1937.

(Fundació Gala-Salvador Dalí: erişim: 16.09.2014 https://www.salvador-dali.org/en/artwork/ catalogue-raisonne-paintings/obra/454/swans-reflecting-elephants?paraulaClau=Swans)

32 Salvador Dali, "The Object as Revealed in Surrealist Experiment” (This Quarter, Paris, 5[1], September 1932), Collected Writings of Salvador Dali, (Ed.) Haim Finkelstein, Cambridge University Press, 1998, s. 238.

33 Pierre Schaeffer, In Search of A Concrete Music, University of California Press, 2012, s.41. 


\section{İdeolojik Anlaşmazlık}

'Sanat ve devrim' sürrealist idealin ayrılmaz iki parçasıdır. Kendilerini isyan uzmanı olarak tanımlayan sürrealistler, 1925 yılında çağdaş eleştirmen kitlesine hitaben yayınladıkları toplu bildiride akımın adını devrimle ilişkilendirerek, gerek gördüklerinde hiçbir eylemden kaçınmayacaklarını net bir dille ifade etmektedirler. ${ }^{34}$ Halkın devrim fikrine hazırlanması için nasıl özgür bir sanata ihtiyaç varsa, tümüyle özgür bir sanata kavuşmak için de yine devrim gerekmektedir. Breton ve Leon Trotsky (1879-1940) imzalarıla Amerika'daki Partisan Review dergisinde yayınlanan Bă̆ımsız ve Devrimci Bir Sanat İçin başlıklı manifestoda bu düşüncenin vurgusu yapılmaktadır. ${ }^{35}$

Sürrealizm ile müzik arasındaki ideolojik uyuşmazlık da bu noktada başlar. Breton'a göre konserler ve salon müzikleri, burjuvaya hizmet etmesinden dolayı Sürrealizmin devrimci ideallerinin karşısındadır. Sürrealistler aynı zamanda, halkın genel geçer beğenisini de aşağı görmektedir. Breton’un, Erik Satie (1866-1925) öncülüğünde bir araya gelen ve sonrasında Les Six adıyla Paris ortamında popülaritesi giderek artan gruba karşı takındığı tavır ve grubun lideri konumundaki Jean Cocteau (1889-1963) için ‘sahte şair' lakabını kullanması bunun bir yansimasidir. ${ }^{36}$

Ancak Breton görmezden gelse de müzikte de benzer çıkışlar yaşanmaktadır. Satie'nin dinlemek için değil, arka planda bizi saran gürültülerle bir bütün olarak algılanmak üzere yazdığı 'mobilya müziği' (musique d'ameublement) bir bakıma, burjuvaya özgü müzikal tatmin duygusuna müdahale olarak görülmektedir. ${ }^{37}$ Diğer taraftan Schoenberg'in, Sürrealizmle neredeyse eş zamanlı ilan ettiği 12 ton müziği de benzer bir karşı duruş içermektedir. Ses dizilerinin anti hiyerarşik yapısı, armonik olduğu kadar sosyal alandaki sınıfsal düzene karşı da bir eleştiri niteliğindedir. Schoenberg'in ticari etkinlikler tarafindan kabul görmeyen müziklerin provası ve icrası için kurduğu Özel Müzik Performansları Derneği (Society for Private Music Performances) de Breton'un toplumun genel beğenisinin karşısında duran yaklaşımına paralellik göstermektedir. Breton gibi Schoenberg de basmakalıp sanat eleştirmenliğine karşı net ve muhalif bir tavra sahiptir ve bu tavrını derneğin etkinliklerine eleştirmenleri almayarak sergilemektedir. ${ }^{38}$

\section{Müzikteki Sürrealist Yansımalar}

Birinci Dünya Savaşı sonrasında müzikteki gelişmeler, farklı yönlere doğru evrilmiştir. Bir yanda eskiyle bağlarını koparmayan Neoklasik müzik anlayışı; diğer tarafta Les Six grubu gibi klasik müziğin ağırlığından kurtulmaya çalışan, sadelik, muziplik ve kolay anlaşılır bir müzik

34 Artaud, Breton, Eluard, Naville, Soupault, Aragon, Ernst, Masson ve diğerleri, 'Sürrealist Araştırmalar Bürosu Bildirisi', (1925), (der). Ali Artun, Sanat Manifestoları: Avangard Sanat ve Direniş, İletişim Yayınları, 2010, s. 226.

35 Lev Troçki, André Breton, 'Bağımsız ve Devrimci Bir Sanat İçin (1938)', (der). Ali Artun, Sanat Manifestoları: Avangard Sanat ve Direniş, İletişim Yayınları, 2010, s. 231.

36 Breton, a.g.e., 2006, s. 350.

37 Albright, a.g.e., s. 68.

38 Slonimsky, a.g.e., s. 137. 
peşinde olan besteciler bulunmaktadır. Tüm bunların arasında Schoenberg ve öğrencileri Alban Berg (1885-1935) ve Anton Webern'le (1883-1945) birlikte 'yeni müzik' in sesi yükselmektedir. Sürrealist sanatçılar ne kadar müzikten uzak durmaya çalışmış olsalar da, bu çeşitlilik içinde, kendini Sürrealist akıma yakın hisseden bestecilerle karşılaşmak mümkündür.

Sürrealist düşüncenin müzikte nasıl yankı bulduğu konusunda farklı görüşler bulunmaktadır. Örneğin LeBaron, 1920’ler ve 1930'lardaki müzikteki sürrealist denemelerin, büyük ölçüde münferit kaldığını ve sürrealist idealin gerçekleştirmesi için gerekli olan teknik ve estetik unsurların edebiyat ve görsel sanatlara eşlik edecek kadar yeterli olmadığını ileri sürmektedir. ${ }^{39}$ Slonimsky ise Breton'un ağırlığını bir kenara koyarak konuyu akımın isim babası olan Guillaume Apollinaire $^{40}$ (1880-1918) üzerinden incelemektedir. Çalışmasında Yeni Klasikçi müzikten dizisel tekniğe uzanan geniş bir çerçevede, içinde sürrealist unsurlar barındıran örneklere yer vermektedir. Albright da Slonimsky gibi Sürrealizmin müzik üzerindeki etkisinin, ancak Breton'un otoriter rejimi bir kenara bırakılabilirse ortaya çıkabileceğini düşünmektedir. ${ }^{41}$

Her ne kadar Sürrealist Manifesto yayınlandıktan kısa bir süre sonra yaşamını yitirmiş olsa da, Sürrealizmin müzikle ilişkisi söz konusu olduğunda adı geçen ilk isim Erik Satie'dir. Albright, öncü bir sürrealist olarak tanımladığı Satie'nin, dönemin bohem yaşamını yansıtan $\ddot{U} c ̧$ Vals'ini (Les trois valses distinguées du précieux dégoûté, 1914), armonik ve absürt çağrışımlarından dolayı bir tür "sürrealist kurgu" olarak tanımlanmaktadır. ${ }^{42}$ Müziklerinde kimi zaman kullandığı tuhaf metinlerin yanı sıra caz tınıları, daktilo, uçak pervanesi, siren ve vapur düdüğü gibi seslere yer vermesi, besteciyi Fütürist ve Dadacı etkiler ile birlikte Sürrealizmi müjdeleyen bir noktaya taşımıştır.

Akım birlikte anılan bir diğer isim, Satie'nin öncüsü olduğu ve Jean Cocteau çevresinde bir araya gelen Les Six grubunun üyelerinden besteci Francis Poulenc'dir (1899-1963). Apollinaire, Paul Éluard ve Louis Aragon gibi sürrealist şairlerle yakın ilişki kuran Poulenc, onların şiirleri için müzikler bestelemiştir. Albright, bu çalışmalarından biri olan, librettosu Apollinaire'e ait Les Mamelles de Tirésias' ${ }^{1}$ (1944) sürrealist opera olarak tanımlayarak, bestecinin izleyici üzerinde baş döndürücü bir etki yaratmak için müzikle metin arasında kasıtlı olarak yanlış bir yorumlamaya gittiğini belirtmektedir. ${ }^{43}$ Slonimsky de aynı şekilde, tonal yapıya bağlı bu müzik ile Apollinaire'in fantastik hikayesi arasındaki tezatlığa dikkat çekmektedir. ${ }^{44}$

Sürrealist hareket ile beraber anılan bir diğer besteci, George Antheil'dir (1900-1959).

39 LeBaron, a.g.e., s. 33.

40 Apollinaire, super-realism [sur-réalisme] terimini ilk kez Parade (1917) balesinin program notlarında kullanmıştır. Senaryosunu Cocteau'nun yazdığı, sahne ve kostüm tasarımı Picasso'ya ait olan bu avangard balenin müziği ise Erik Satie'ye aittir. Sirkte düzenlenen bir geçit töreninin canlandırıldığı bu eser Apolliaire'e göre; sanatı, bilim ve endüstrideki gelişmeleri yakalayacak bir seviyeye çıkarmıştır. Hepsinden önemlisi bu bale bir tür 'gerçekliği dönüştüme sorgusu'dur (Gulliame Apollinaire, "Program Note for Parade" (1917), (Ed.) Daniel Albright, Modernism and music: An Anthology of Sources, 2004, s. 320).

41 Albright, a.g.e., s. 310.

42 Albright, a.g.e., s. 321.

43 Albright, a.g.e., s. 103.

44 Slonimsky, a.g.e., s. 135. 
Satie gibi modern zamanın seslerini müziğine aktaran bu Amerikalı besteci Avrupa'nın avangard ortamına dahil olmuş bir isimdir. Fernand Legér'in (1881-1955) yönettiği, Man Ray'ın (1890-1976) de sinematografik katkılarıyla oluşan Mekanik Bale (Ballet Mécanique, 1924) için yazdığı müzikte sekiz piyano, iki elektrikli zil ve uçak pervaneleri kullanmıştır. ${ }^{45}$ Besteci, Faust III operası için Aragon ve Breton ile çalışmaya başlasa da iki şair arasındaki anlaşmazlıktan dolayı bu proje tamamlanamamıştır. ${ }^{46}$

Antheil'in, 1935 yılında Max Ernst'in grafik romanı 100 Başsız Kadın (La Femme 100 Têtes 1929) için yazdığı eseri ise Sürrealizm etkisini sahne müziklerin dışına çıkartan bir örnektir. Ernst'in 19. yüzyıl gravürlerini kullanarak yarattığı bu eser, 9 bölümden oluşan bir kolaj romandır. Kitaptaki her görsel, can alıcı ve tuhaf bir resim altı yazısıyla birlikte sunulmuştur (F.4). Antheil, bu kitaptan yola çıkarak 45 prelütten oluşan bir müzik dizisi bestelemiştir. Metinler gibi bir solukta dinlenen bu kısa parçalar dinleyiciyi kendi düş gücüyle baş başa bırakmaktadır.

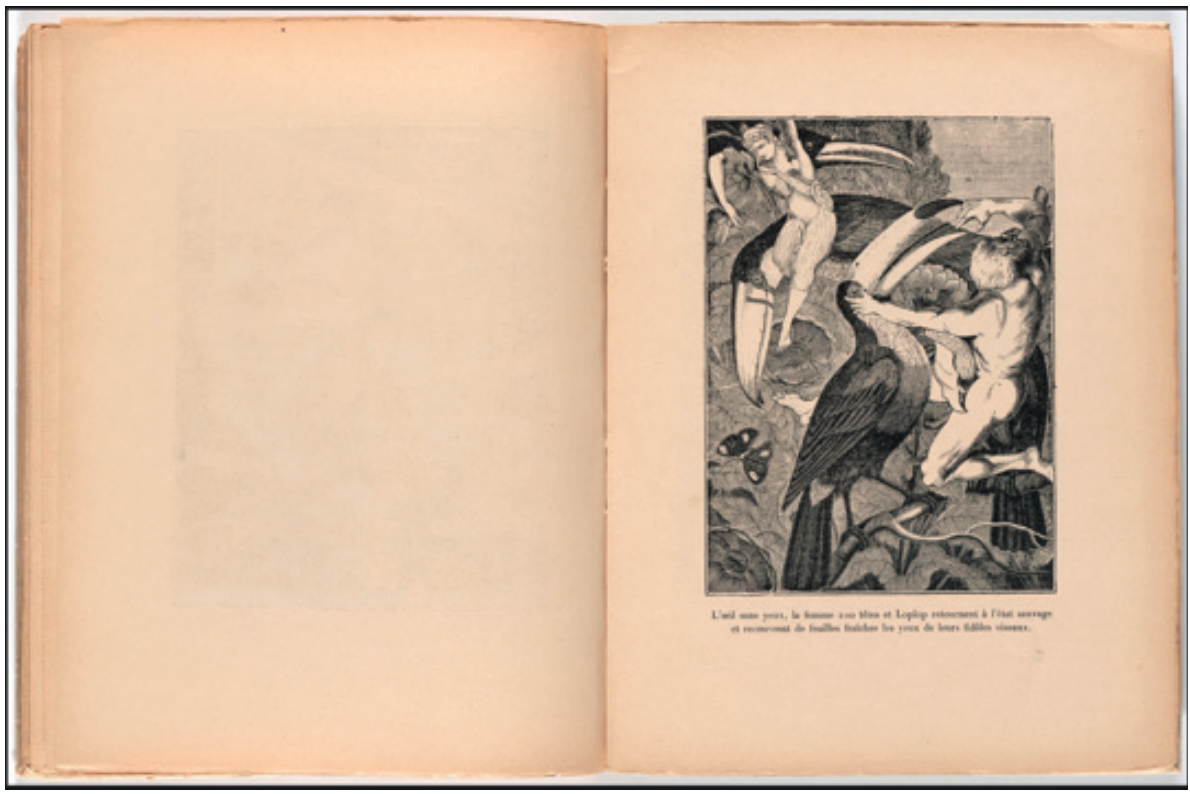

F. 4: Max Ernst, La Femme 100 Têtes, $25.1 \times 19.2 \mathrm{~cm}$, kolaj kitap (Paris: Éditions du Carrefour), 1929.

(Moma: erişim 12.01.2020 https://www.moma.org/collection/works/229544)

45 Birinci Dünya Savaşı sonrası Avrupa'sında, sanatçıların bir araya getiren projeler oldukça yaygındır. Bu dönemde sahne tasarımında çalışmayan sanatçı neredeyse yok gibidir. Satie'nin son dönem işlerinden biri olan, Relâche balesi (1924) bunlardan biridir. Bestecinin Picabia ile birlikte çalıştığg bu balede, Marcel Duchamp ve Man Ray'ın katkıları olmuştur, bölüm aralarında ise René Clair'in avangard filmi Entr'acte gösterilmiştir. LeBaron, a.g.e., s.31. 
Ancak, Antheil de dahil olmak üzere yukarıdaki bestecilerin hiç biri, müziğinde barındırdığı sürrealist unsurlara rağmen sürrealist hareketin resmi bir üyesi olmamıştır. Bu noktada André Souris, şair ve besteci kimliği ile Belçikalı sürrealist çevrenin resmi bir üyesi olarak diğerlerinden ayrılmaktadır. 1925'den, ihraç edildiği 1936 yılına kadar sürrealist grupta kalan bestecinin müziği Stravinsky ve Satie etkisinde biçim almıştır. 1929 yılında Nougé ve Magritte ile beraber düzenledikleri etkinlikteki konser programına, kendi müziğinin yanı sıra Arnold Schoenberg, Paul Hindemith (1895-1963), Darius Milhaud, Igor Stravinsky ve Arthur Honegger'in eserlerini dahil etmiştir. Bu etkinlikte, Magritte'in yirmiye yakın resmi sergilenmiş ve Nougé ise Müzik Tehlikelidir başlıklı konferansı gerçekleştirmiştir. Sürrealist ideallere bağlılığının yanı sıra gestalt teorileri, varoluşçuluk, yapısalcılık ve göstergebilimle de yakından ilgilenen Souris, 1945'den sonra dizisel müziğe yöneltmiş; Pierre Boulez (1925-2016) ve Henri Pousseur (1929-2009) gibi genç kuşak müzisyenlerin örnek aldığı bir besteci olmuştur. ${ }^{47}$

Souris, her ne kadar sürrealist bir geçmişe sahip bir besteci olarak dizisel müzik uygulamalarına yönelmiş olsa da 1950'lere uzanan süreçte, dizisel müziğin gelişimi ile Sürrealizmin ilişkisi üzerine çok az şey söylenmiştir. Oysa ki bu müziğin çıkış noktası olan Schoenberg'in 12 ton tekniği, müzikte devrim niteliğinde bir yenilik olarak, Sürrealizmle hemen hemen aynı zamanda ortaya çıkmıştır. Slonimksy, 12 ton müziğinin melodik olarak sürrealist bir etki yarattığını düşünse de Schoenberg okulunu tarihsel perspektifte dışavurumculuğa daha yakın görmektedir. ${ }^{48}$ Nitekim LeBaron'a göre de dizisel müzikteki ilk denemeler sürrealist estetikten çok uzaktır. ${ }^{49} \mathrm{Bu}$ uzaklığın temel nedeni, yaratım sürecinde birbirlerinin tam karşıtı olan yaklaşımları benimsemiş olmalarıdır. Biri düşüncenin bütünüyle serbest bırakılmasından (otomatizm), diğeri ise kontrolü elinde tutmaktan (önceden belirleme) yanadır.

\section{Raslamsallığa Giden Yolda Dizisel Müzik ve Sürrealizm}

12 Ton tekniği, Schoenberg'in yüzyıl başında atonal müzikte başladığı yolculukta geldiği yerdir. Besteci, yüzyıllar boyu armonik değerler içine sıkışmış ses alanının açılmasına imkan sağlayacak bir çıkış yolu olarak gördüğü bu tekniği, 1922 yılında duyurmuştur. Kısaca bu yazı, kromatik gamdaki 12 yarım sesin, bestecinin seçimine göre belirlenen bir düzende, her biri sadece bir kez kullanılacak biçimde dizilmesiyle oluşmaktadır. Müzikteki melodi, belirli kurallar gözetilerek çeşitlenen bu dizilerle yaratılmaktadır. ${ }^{50}$

47 Edward Campbell, Boulez, Music and Philosophy (Music in the Twentieth Century), Cambridge University Press, 2010, s. 26.

48 Slonimsky, a.g.e., 139.

49 LeBaron, a.g.e., 31.

5012 sesin her biri, bağımsız olarak bir değere sahiptir. Bu eşitlikçi ilke sesler arasındaki hiyerarşiyi de ortadan kaldırmıştır. 12 ses bir kez duyulduktan sonra başka bir dizilimle tekrarlanır. Tekrarlanan dizinin bir diğeriyle aynı olmaması ön koşuldur. Bunun için de ses dizisi, sondan başa ya da tersine bir sistemle yeniden düzenlenir. Aralıkların kimi zaman yukarıdan aşağıya, kimi zaman da aşağıdan yukarıya çevrilmesiyle de başka yeni düzenler yaratılmış olur. Düzeni sağlamak için ise yoğun olarak matematikten, matematiğin permutasyon ve matris sisteminden yararlanılmaktadır. 
Dizilerin farklı türevleriyle bir araya gelmesiyle oluşan bu müzik, Schonberg'in öğrencileri Alban Berg ve Anton Webern'in çalışmaları ile olgunluğa erişmiştir. Devrim niteliğinde bir çıkış olarak değerlendirilse de bu müziğin bestecileri geldikleri noktayı, tarihsel gelişmelerin bir sonucu olarak görmektedir. Örneğin; bu tekniği titizlikle uygulayan Webern'e göre diziler "kanun" gibidir. Besteci, Yunanca "nomos" kelimesinin hem kanun hem de melodi anlamına geldiğini hatırlatarak, tıpk1 her buz kristallerine farklı biçimler veren doğa yasası gibi sesin kromatik evreninin düzenlenmesi için de en ideal yolun dizi kurallarını uygulamak olduğunu belirtmektedir. ${ }^{51}$

Ancak müziğe biçim veren ve bestelenme sürecinde titizlikle hesaplanan bu diziler, dinlemede fark edilmemektedir. Öte yandan armonik değerlerin dışına çıkan müziğin akış yönünün öngörülememesi de dinlenme sürecini zorlaştırmaktadır. Slonimsky bu durumun, sürreal bir etki yarattığını düşünmektedir. Doğrusu, dinleyicinin aşina olduğu müzik dünyasına ait sesler, hiç olmadık biçimde yeniden sunulmaktadır. Müziğin kabul gören mantıksal dili, yine onun öğeleri ve imkanlarıyla bozulmakta ve bu bozulma bir anlamda, kabul görmüş müzikal gerçeklik içinde yeni bir gerçeklik olgusu yaratmaktadır.

Sürrealizm ile dizisel müziğin arasındaki benzerlik, her ikisinin de çıkış noktası olarak belirlediği temel ilkelerin bir süre sonra yetersiz kalmasıyla ortaya çıkmaktadır. Breton’un otomatizmi aşırı kontrolsüzlükten, Schoenberg'in tekniği ise tekdüze kalmış bir kontrolden dolayı tıkanma noktasına gelmiştir. Dali ve Ernst gibi sürrealist sanatçılar bu tıkanıklığa kendi geliştirdikleri yeni uygulamalarla çözüm üretmiş; sanatsal eylemi pasiften aktif olana, sistemsizden sistemli olana yöneltmişlerdir. Dizisel müzikteki aşırı kontrolün geldiği tıkanma noktasına çözüm önerisi ise Pierre Boulez'den gelecektir.

Boulez, mistik ve dinsel temaları müziği ile birleştiren ve elektro-akustik gelişmeleri yakından takip eden Olivier Messiaen'in (1908-1992) öğrencisidir. Kendinden önceki kuşaktan takip ettiği diğer isimler arasında Schoenberg, Webern, Stravinsky, Debussy (1862-1918), Souris ve Varése (1883-1965) yer almaktadır. Çağdaşları arasında ise John Cage ve Karlheinz Stockhausen ile yakın ilişkide olmuştur. Bestecinin felsefe, edebiyat ve görsel sanatlarla duyduğu ilgi ses dünyasını beslemiştir. Erken döneminde Réne Char ve Antonin Artaud gibi sürrealist grubun üyesi olan sanatçılara yakın duran Boulez, müzik hakkındaki düşüncelerini de yine bu sanatçıların görüşleri 1şı̆̆ında biçimlendirmiştir. 1948 tarihli Proposals başlıklı yazısında Artaud'un fikirlerinden hareketle müziği, 'kolektif bir histeri hali' olarak tanımlamıştır. Darmstadt yaz okulunda verdiği derslerde Breton ve Aragon'un metinlerinden yararlanan ${ }^{52}$ Boulez, 1951 yılında Schoenberg'in ölümünden kısa bir süre sonra yayınladığı Schoenberg Öldü (Schoenberg is Dead) yazısıyla da sürrealist hareketin tartışma yaratan ve devrimci yaklaşımına yaraşır bir sansasyona imza atmıştır.

Boulez, Schoenberg'i dizisel yöntemde daha ileri gitmediği için eleştirmektedir. Ona göre bu yöntem sadece biçimsel bir müdahale olarak kalmıştır. ${ }^{53}$ Besteci, dizilerin sadece ses

51 M.J Grant, Serial Music, Serial Aesthetics: Compositional Theory in Post-War Europe (Music in the Twentieth Century), Cambridge University Press, 2005, s. 90.

52 Campbell, Edward, a.g.e., s. 31.

53 Pierre Boulez, "Schoenberg is Dead", Notes of an apprenticeship, New York, A.A. Knopf, 1968, ss.268-275. 
yüksekliği değil ritim, ses gürlüğü ve ses rengi gibi diğer müzikal öğeler için de kullanılmaya başladığında biçimsellikten çıkarıp birleştirici bir söyleme dönüşebileceğini düşünmektedir. ${ }^{54}$ Ancak tekniğin tüm öğeleri kapsayacak biçimde birleştirici bir role sahip olması, aynı zamanda müziğe kuru ve tekdüze bir kişilik kazandırmaktadır. Boulez bu noktada, besteleme sürecine otomatizmi dahil ederek yeni bir özgürlük alanı açmaya çalışmıştır. 1951-52 tarihli Structures eseri üzerine çalışırken otomatizmi nasıl tecrübe ettiğini şu sözlerle anlatır:

“İlk parça, tek bir gecede çok hızlı bir şekilde yazıldı, çünkü verili bir ses malzemesinin potansiyeli ile otomatizmin bir müzikal ilişkide ne kadar uzağa gideceğini keşfetmek istedim. Benim müdahalelerim yalnızca çok basit biçimlendirmelerde, örneğin yoğunluklar konusunda kendini gösteriyor. Bu amaçla, Messiaen'in Mode De Valeurs et d'intensités'inden ses malzemesi ödünç aldım. Böylece mümkün olduğu kadar ileri gidebileceğim ve kendim yaratmadığım bir malzemeye sahip oldum. Tüm transpozisyonları, her yöne hareket eden mekanik bir nesne gibi yazdım ve kendi rolümü ses aralıklarının seçimi ile sınırladım - fakat böyle bile tam olarak farklılaşamadı." ${ }^{55}$

Boulez otomatizm ile elde edemediği sonucu, Cage'ın 'şans müziği'ni kendine göre uyarlayarak gerçekleştirecektir. ${ }^{56}$ Şans operasyonlarının (chance operations) temelinde yatan düşünce, bestecinin bilinçli yaratıcı gücünü terk etmesini sağlamaktır. Bu teknikle yazılan müziklerde notalara karar vermek için zar atmak, yazı tura atmak gibi şans ile belirlenen yöntemler kullanılmaktadır. Bir bakıma, Breton'un otomatizmindeki gibi besteciye sınırsız bir özgürlük alanı açılmaktadır. Ancak Boulez kontrollü bir özgürlükten yanadır. Fazla esnetilmiş düzenlemelerde müzikal fikrin kaybolacağını düşünmektedir.

Cage ve Boulez arasındaki fark, müzikteki açıklık fikrine iki farklı yoldan ulaşılmasını sağlamıştır. İlkinde (Cage'in şans operasyonları) besteci, kontrolünü kendi belirlediği yöntemlerle bırakır ve böylece eserin yazılma anına tam bir esneklik getirir. İkincisinde (raslamsal) ise açıklık düşüncesi eserin icrası sırasında gerçekleşir. Buna göre besteci herhangi bir yöntem ile bestelediği eserinde, icracının kendi tercihini kullanabileceği alanlar yaratmaktadır (F.5). Boulez 1951 tarihinde Cage'e yazdığı mektubunda otomatizmin olgusunu bu şekilde yönlendirmenin mümkün olduğuna inandığını belirtmektedir. ${ }^{57}$ Böylece bestecinin, eserin bütünü üzerindeki hakimiyetini kırılmakta; müzik ise icracı, besteci ve dinleyici arasında, her çalınışında farklı olasılıklar barındıracak biçimde yeniden tanımlanmaktadır.

54 Aaron Copland, Yeni Müzik (1900-1960), çev: Ali Cenk Gedik, Yazılama Yayınevi, 2015, s. 163.

55 Peter F Stacey, Boulez and Modern Concept, University of Nebraska Press, 1987, 23-24).

56 1940'larda hazırlanmış piyano gibi düzeneklerle çalgıların ses üretimi değiştirebileceğini keşfeden John Cage, daha sonra ortaya koyduğu şans operasyonları ile raslamsal müziğin çıkış noktasını belirleyen kişi olarak kabul edilmektedir (Copland, Aaron, a.g.e., s. 166).

57 Pierre Boulez, The Boulez-Cage Correspondence, (ed.) Jean-Jaque Nattiez (ed.) Robert Samuels, Cambridge University Press, 1995. s.112. 


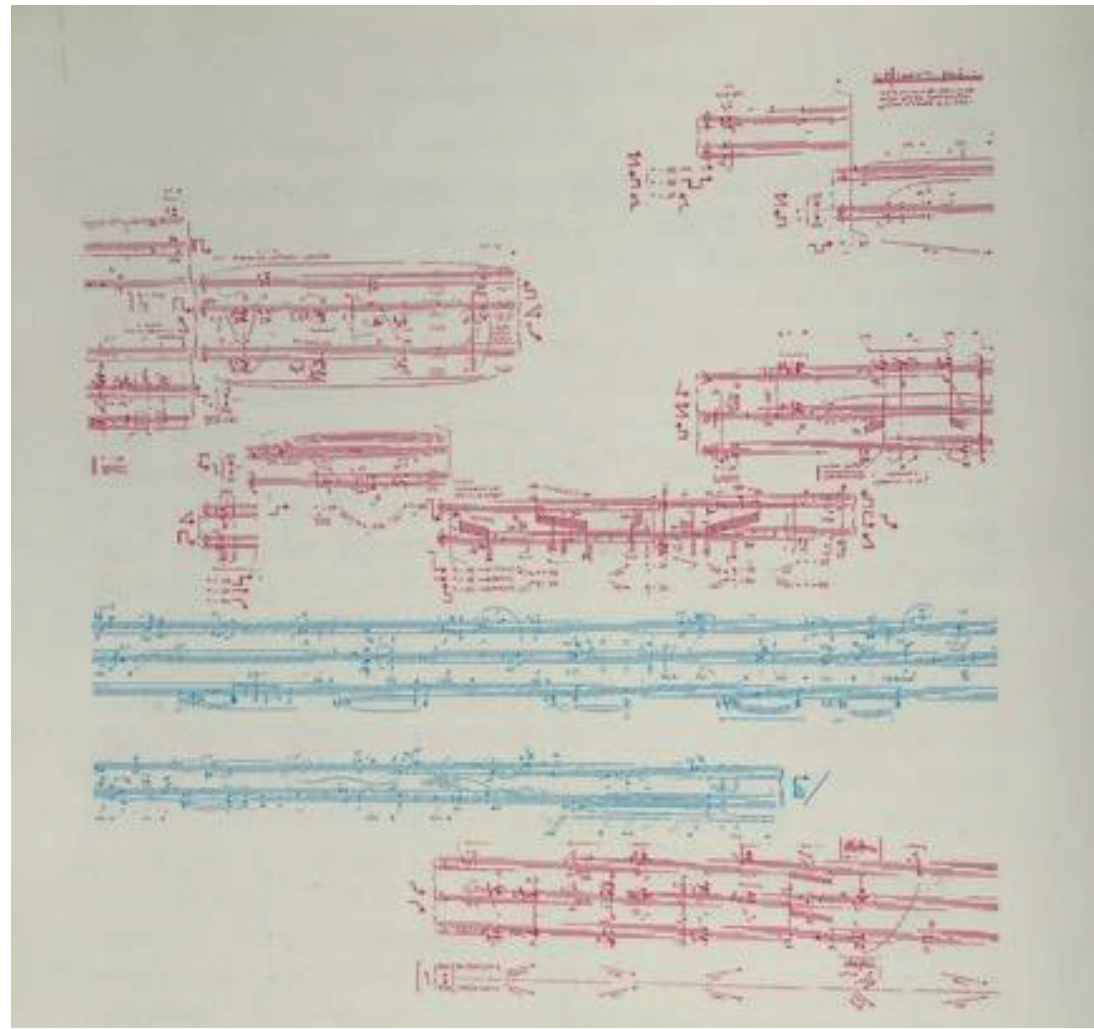

F. 5: Pierre Boulez, Troisiéme sonate pour piano - formant 3 - Miroir, 1957. (Jean Yves Bosseur, Sound And The Visual Arts: Intersections Between Music and Plastic Arts Today, Dis Voir, 1993, resim no:18, s.78)

\section{Değerlendirme ve Sonuç}

Zaman içinde tekdüze ve aşırı kontrollü bir pratiğin içine sıkışmış olan dizisel müziğin, çıkış noktasını otomatizm gibi sürrealist yöntemlerde araması ve bu deneyimlerin raslamsal müzik ve onu bir adım öteye taşıyan grafik notasyon uygulamaları için uygun bir zemin hazırlamış olması, Sürrealizm müzik ilişkisine yeni bir bakış kazandırmaktadır. Buna paralel olarak sürrealist sanatçıların da kontrollü bir serbestliği kendi sanatlarında uyguladığı görülmektedir. Dali, yıllar içinde geliş̧tirdiği paranoyak kritik yöntemin son haline biçim verdiği Ustalığın Sihirli 50 Sirrl (50 Magic Secrets of Craftmanship, 1948) ve birkaç yıl sonra yazdığı Mistik Manifesto'da (Mystical Manifesto, 1951) sanatını mistisizm yanında matematiksel hesaplamalar ve altın oran gibi klasik sanatların teknik becerilerine temellendirdiğini ilan etmiştir. Dali'ye göre, kompozisyonun yapısal kurgusunda önceden belirlenen yönlendirmeler sanatçıyı resmin ötesine taşıyan bir pusula, zihni serbest birakmaya yarayan bir rehber görevi görmektedir (F.6-7).$^{58}$

58 Salvador Dali, “Mystical Manifesto" Collected Writings of Salvador Dali, (Ed.) Haim Finkelstein, Cambridge University Press, 1998, s. 363. 


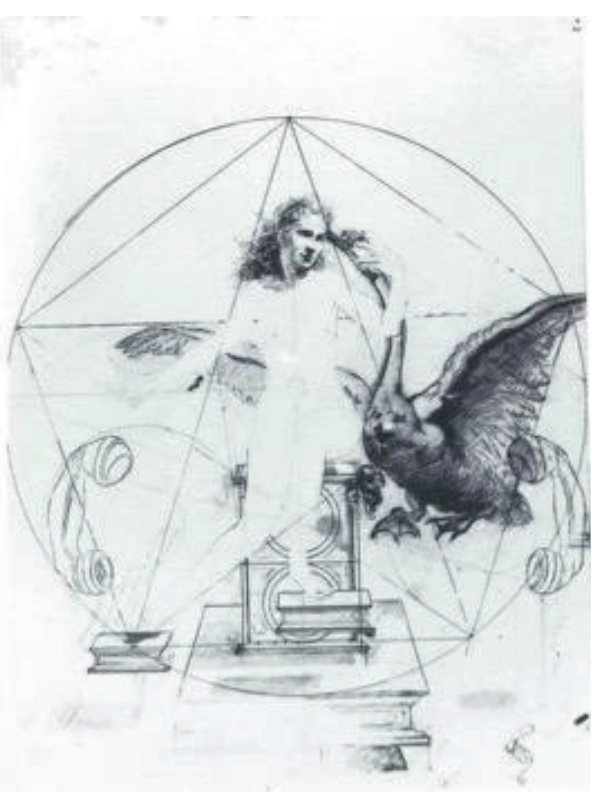

F. 6: Salvador Dali, Leda Atomica için taslak çizim (Boceto para Leda Atomica), 1947. (Salvador Dali Catalogo Mostra Palazzo Dei Diamond Ferrara 1984, s.278)

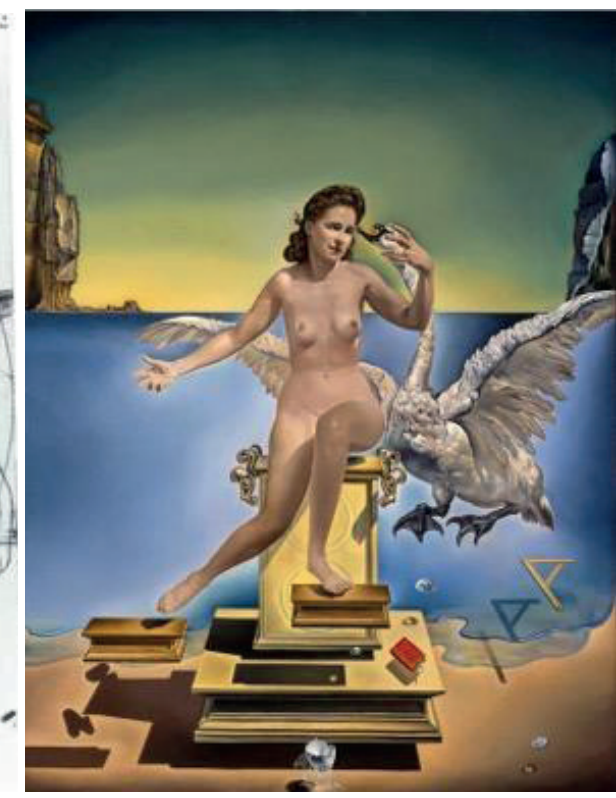

F. 7: Salvador Dali, Leda Atomica, tuval üzeri yağlıboya, $61 \mathrm{~cm} \mathrm{x} 46 \mathrm{~cm}$, Fundació Gala-Salvador Dalí, Figueres 1949. (Fundació Gala-Salvador Dalí: erişim: 12.05.2015) https://www. salvador-dali.org/en/artwork/catalogueraisonne-paintings/obra/642/ledaatomica?paraulaClau=Leda+Atomica)

Sonuçta Breton'un müzik üzerine yazdığg ilk ve son metin olan Suküt Altındır'da sözünü ettiği, ancak her iki sanatın prensiplerinin yenilenmesiyle gerçekleşecek bir yakınlığın, dizisel müzik ve sürrealist uygulamalar özelinde gerçekleştiği düşünülebilir. Nitekim, tıpkı sürrealist düşüncenin yayılması gibi, 1950'lerde tüm dünyaya dalga halinde yayılan dizisel müziğin etkisinden kaçmak mümkün değildir. Buradan hareketle konuya derinlik kazandıracak bir örnek olarak çağdaş Türk bestecisi İlhan Usmanbaş’ın (d.1921) 1952-1955 yılları arasına bestelediği Dali'den Üç Resim eseri dikkat çekicidir.

Usmanbaş bu eseri kısa süre denediği 12 ton tekniğinden sonra Boulez'in etkisi ile dizisel müziğe yöneldiği bir dönemde yazılmıştır. Eser aynı zamanda bestecinin geleneksel notalama kalıplarının dışına çıkarak ileride yöneleceği raslamsal müziğin de ip uçlarını vermektedir. ${ }^{59}$

59 Dali'den Üç Resim, gerek besteleme tekniği gerekse de Salvador Dali'nin resimleriyle kurduğu ilişki dolayısıyla özgün değere sahip bir eserdir. Ancak esere ait yalnızca el yazması notası ile 1979 yılına ait bir radyo kaydı bulunması, Dali'den Üç Resim'in geniş kitlelere ulaşmasını ve onun hakkında yapılacak çalışmaları kısıtlamaktadır. İTÜ Bilimsel Araştırma Projeleri desteğiyle gerçekleşen 'Sanat Tarihi, Müzik ve Dijital Medya' projesi kapsamında öncelikli olarak esere konu olan Dali'nin üç resimden bugüne kadar tespit edilmemiş olan ikisi, Uyumlu Parçalanan Melek (Angel Explodanto Armonicamente, 1951) ve Kentaur (El Centauro, 1951) tespit edilmiş; oluşturulan bir 
Nitekim, bir söyleşisinde dizisel müziği, rastlamsallığa giden yolda onun kaçınılmaz bir diyalektiği olarak gördüğünü dile getirmiştir:

“Rastlantıyı köktenleştirme düşüncesi çok eskiden beri vardı (eski Çin’deki ünlü I-Ching tablaturaları gibi), ama yüzyılımızın başında Gerçeküstücülerle, önce edebiyatta ortaya çıkan, daha sonra Amerika'da resim ve müzikte, özellikle müzikte, kesin tasarım yöntemlerinin (tüm dizisellik gibi) en uç noktaya geldiği bir dönemde, onunla birlikte çıktı ortaya, kaçınılmaz bir diyalektik olarak." ${ }^{60}$

Usmanbaş Dali'den Üç Resim 'in dizisel örgütlenmesini, Dali'nin son dönem çalışmalarından seçtiği üç resmin plastik kuruluşu üzerinden gerçekleştirmiştir (F.8, F.9.F.10). Resimlerde yer alan figürleri ayrı ayrı ele almak yerine bütünde sundukları biçimsel yapıyla, resmin ana iskeletini oluşturan çizgisel unsurlarla ilgilenmiştir. Kütlesel iniş çıkışlar, gerilim ve dinginlik, bütünlük ve dağılma gibi eş zamanlı karşıtlıkları müziğine aktaran besteci; keman, viyola, viyolonsel ve kontrbastan oluşan 22 yaylı orkestrayı da 22 tuşluk bir piyano gibi bir bütün olarak düşünmüştür. ${ }^{61}$ Besteci bu bütünlüğü, ölçü çizgilerini kaldırdığı ve vuruşların nota değeri olarak partisyon dışına taşındığı kağıt üzerinde de vermeye çalışmıştır.

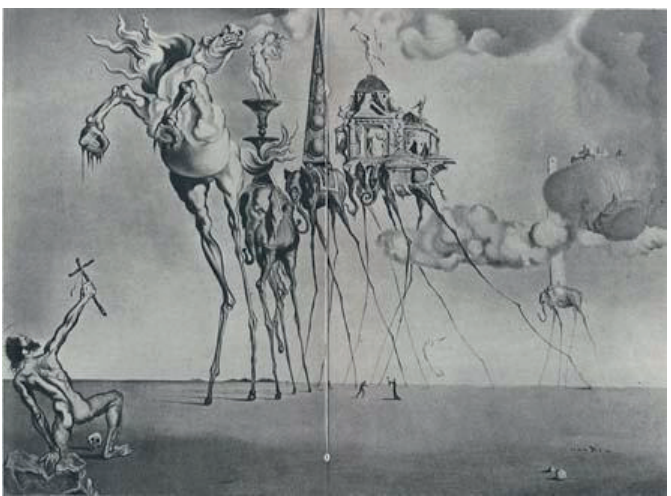

F. 8: Salvador Dali, Las Tentaciones de San Antonio (Aziz Antonio'nun Sinanmas1), 1946,

Tuval üzerine yağlıboya, 89.7 x $119.5 \mathrm{~cm}$, Brussels, Belgium.

(Raphael Santos Torroella, Salvador Dali, Afrodisio Aguado, S.A Madrid, 1951, resim no: 9)

orkestra ile eserin stüdyo kaydı alınmış; ve son olarak Usmanbaş'ın müziğinin Dali’nin resimleriyle ilişkisinin incelendiği bir görsel-işitsel konser etkinliği düzenlenmiştir. Proje sonunda elde edilen tüm kayıtlar için bkz. http://daliden3resim.itu.edu.tr/

60 Evin İlyasoğlu, "İlhan Usmanbaş ile Söyleşi”, Soyut Edebiyat Dergisi, No:102, 1977, ss. 52-62.

61 Evin İlyasoğlu, İlhan Usmanbaș: Ölümsüz Deniz Taşlarıydı, YKY, 2001, s.106. 


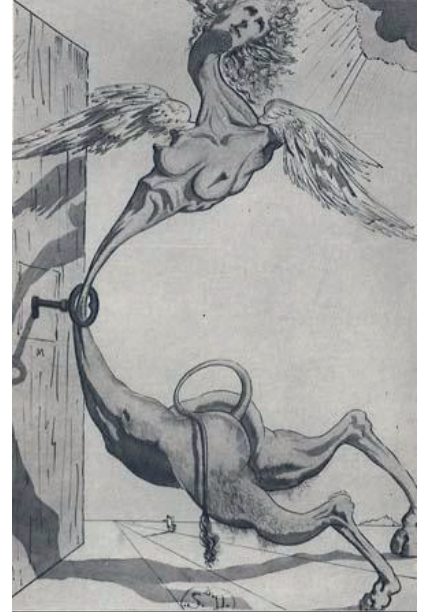

F. 9: Salvador Dali, El Centauro (Kentaur), 1951, Çini mürekkebi ve kalem, 77,5x54,4 cm. (Raphael Santos

Torroella, Salvador Dali, Afrodisio Aguado, S.A, Madrid, 1951, resim no: 10)

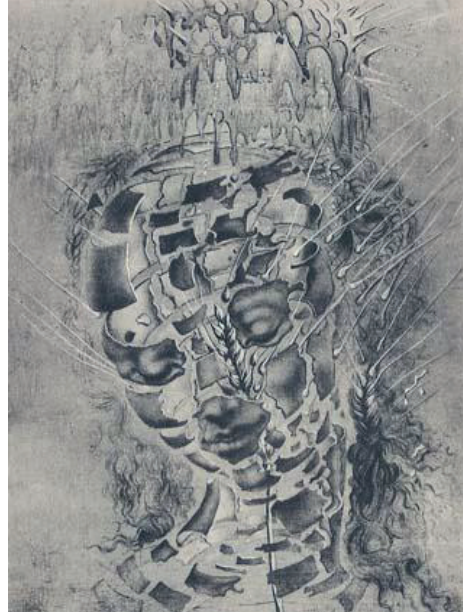

F. 10: Salvador Dali, Angel Explotando Armonicamente (Uyumlu Parçalanan Melek), 1951, pano üzerinde yağl1 boya, guaj ve kalem, 24.2 x $19 \mathrm{~cm}$, Özel Koleksiyon. (Raphael Santos Torroella, Salvador Dali, Afrodisio Aguado, S.A, Madrid, 1951, resim no: 27)

Ölçü rakamı ve ölçü çizgisi, müziği zamansal organizasyonunu yaratan temel öğelerdir. Dali'den Üç Resim' de Usmanbaş, bu hiyerarşik yapıdan kurtarmak için ölçü çizgilerini kaldırmış ve ölçü rakamlarını da portenin dışına taşıyarak notasal değerler olarak göstermiştir (F.11). Bu yaklaşımı kendi deyimiyle "zamansal [müzikal] ve uzamsal [resimsel] olanın kuruluş mantığının nerelerde çakıştı̆̆ını, nerelerde birinden öbürüne geçebileceğini araştırma" çabası olarak tanımlamaktadır. ${ }^{62}$ Usmanbaş böylece, Nougé'un müziği görme eylemi ve yaşadığımız tecrübelerle tanımladığımız form ve hareketle ilişkilendirdiği bir anlayışa yakın bir duruş sergilemektedir. Öte yandan besteci müzikal zamanın akışını, parçalara bölünmüş olarak değil, bir anda idrak edilen ve 'gerçek' uzunluk duygusunu yaratacak biçimde ortaya çıkarmayı amaçlamıştır. ${ }^{63}$

Usmanbaş, sınırlı tanımlamaların müziği eksik bırakacağını düşünen bir bestecidir. Nougé gibi müziği hem elle tutulur somut bir dünyada hem de bir deneyim olarak algısal dünyaya ait olarak görmektedir. Müzik Usmanbaş'a göre; bir yanda sayfa üzerinde, belirli bir sisteme dayandırılarak oluşturulan notalaşmış ya da grafikleşmiş bir görüntü olarak vardır; diğer tarafta ise müzik, bu olayı yaşayan kişinin (bestecinin, icracının, dinleyicinin) tecrübesi ve algısıyla işlev kazanmaktadır. ${ }^{64}$

62 İlhan Usmanbaş, Müzik Dilinin Mantığı, Felsefe ve Sanat Sempozyumu (ed.) Ömer Naci Soykan, Ara Yayıncılık, İstanbul, 1990, s149-154.

63 Evin İlyasoğlu, 2001, (a.g.e) s.106.

64 İlhan Usmanbaş, 1990, (a.g.e). 
Dizisel müzikten raslamsal uygulamalara doğru çözülmeyi yaşamış bir besteci olan Usmanbaş, sürrealist düşüncenin 1950 sonrasında müzikteki yansıması olarak değerlendirilen caz müziği ve müzikteki post-modern uygulamaların öncesinde bir örnek sunmaktadır. Dahası “Dali'den Üç Resim” yalnızca iki farklı sanatsal pratiği birbirine yakınlaştırmakla kalmayıp, iki sanatçının 1950'lerin başındaki arayışlarına 1şık tutarak, yaşadıkları değişimin ve deneyimin benzer yönlerini keşfetmemize, dahası dizisel müzik ile Dali’nin resimlerinde uyguladığı sistemli yaklaşım arasındaki olası ilişkiyi görmemize de olanak sağlamaktadır.

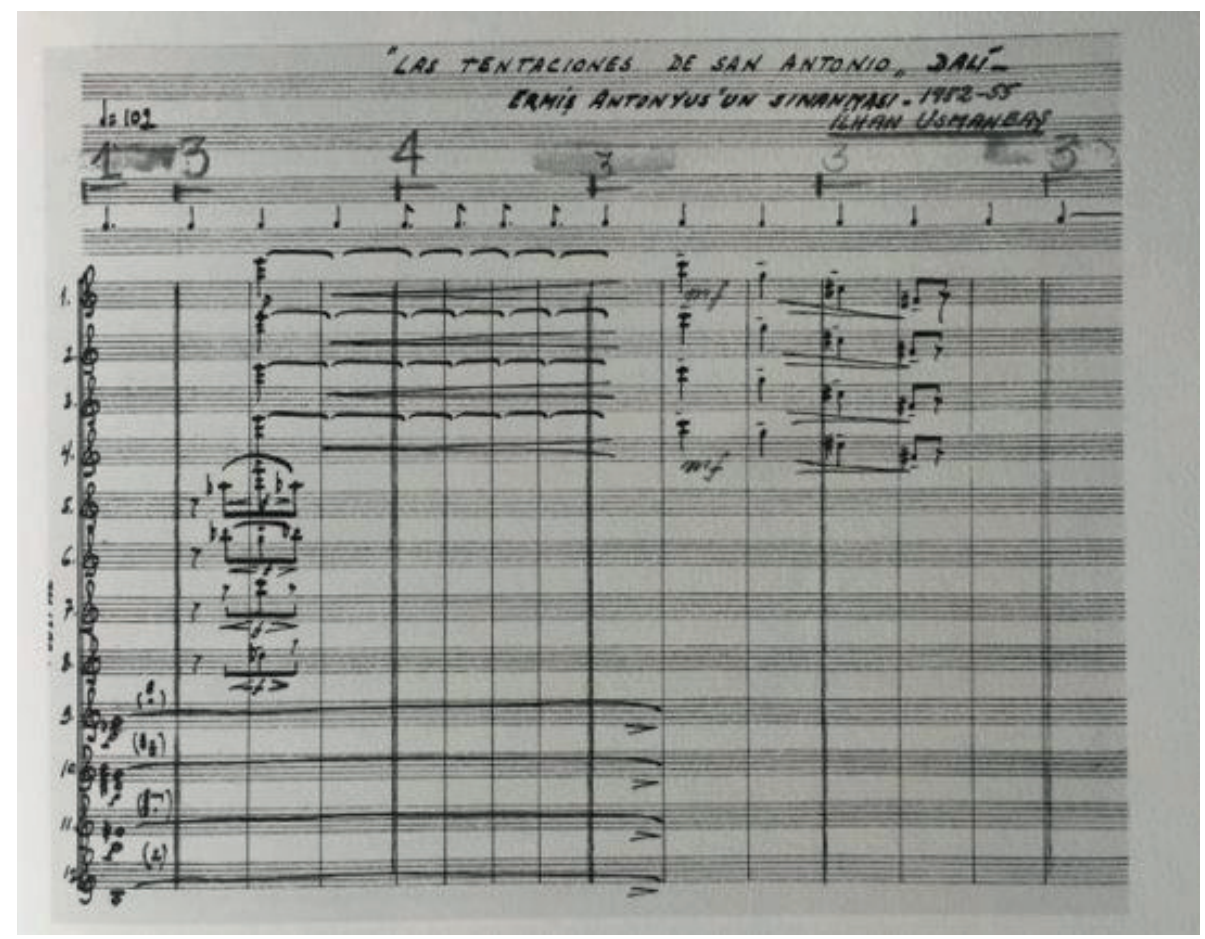

F. 11: Dali’den Üç Resim, 1. Bölüm (giriş). Partisyondaki ölçü çizgilerinin ve rakamların icranın kolaylığı için sonradan orkestra şefi tarafından eklendiği düşünülmektedir.

(Turgut Pögün, Perpetuum Mobile: İlhan Usmanbaş'ın Yapıtı, (ed.) Aykut Köksal, (ed.) Mehmet Nemutlu, (ed.) Kıvılcım Yıldız Şenürkmez, Pan Yayıncılık, 2015, p.191). 
Hakem Değerlendirmesi: Dış bağımsız.

Çıkar Çatışması: Yazar çıkar çatışması bildirmemiştir.

Finansal Destek: Yazar bu çalışma için finansal destek almadığını beyan etmiştir.

Peer-review: Externally peer-reviewed.

Conflict of Interest: The author has no conflict of interest to declare.

Grant Support: The author declared that this study has received no financial support.

\section{Kaynakça/References}

Albright, Daniel (Ed.), Modernism and Music: An Anthology of Sources, University of Chicago Press, 2004.

Artun, Ali (Ed.), Sanat Manifestoları: Avangard Sanat ve Direniş, İletişim Yayınları, 2010.

Artun, Ali, Nur Altınyıldız (Ed.), Sürrealizm / Mimarlık, İletişim Yayınları, 2014.

Breton, André, "Silence is Golden", What is Surrealism? Selected Writings, (Ed.) Franklin Rosemont, Pathfinder Press, 2006, s.348-353.

Breton, André, Sürrealist Manifestolar, Altıkırkbeş Yayın, 2009.

Campbell, Edward, Boulez, Music and Philosophy (Music in the Twentieth Century), Cambridge University Press, 2010.

Chenieux-Gendron, Jacqueline, Surrealism, (çev.) Vivian Folkenflik, Colombia University Press, 1990.

Copland, Aaron, Yeni Müzik (1900-1960), (çev.) Ali Cenk Gedik, Yazılama Yayınevi, 2015.

Dali, Salvador, “Art Film, Antiartistic Film” (1927), Collected Writings of Salvador Dali, (Ed.) Haim Finkelstein, Cambridge University Press, 1998, s.53-57.

Dali, Salvador, "The Object as Revealed in Surrealist Experiment" (This Quarter, Paris, 5[1],

September 1932), Collected Writings of Salvador Dali, (Ed.) Haim Finkelstein, Cambridge University Press, 1998, s. 234-244.

Dali, Salvador, "The Sanitary Goat", Collected Writings of Salvador Dali, (Ed.) Haim Finkelstein, Cambridge University Press, 1998, s. 226-231.

Dali, Salvador, "The Short Critical History of Cinema” (Abrégé d'une Historie Critique du Cinéma, 1932)

Collected Writings of Salvador Dali, (Ed.) Haim Finkelstein, Cambridge University Press, 1998, s. 137-141.

Finkelstein, Haim (Ed.), Collected Writings of Salvador Dali, Cambridge University Press, 1998.

Garon, Paul, Blues and the Poetic Spirit, City Lights Publishers, 1996.

Grant, Morag Josephine, Serial Music, Serial Aesthetics: Compositional Theory in Post War Europe

(Music in the Twentieth Century), Cambridge University Press, 2005.

İlyasoğlu, Evin, "İlhan Usmanbaş ile Söyleşi”, Soyut Edebiyat Dergisi, 1977.

Jenny, Laurent, Thomas Trezise, "From Breton to Dali: Adventures of Automatism", October, Vol. 51, MIT Press, 1989.

Kramer, Jonathan D., Postmodern Music Postmodern Listening, (Ed.) Robert Carl, Bloomsbury Academic, 2016.

LeBaron, Anne, "Reflections of Surrealism in Postmodern Musics", Postmodern Music / Postmodern Thought, (Ed.) Judy Lochhead, Joseph Auner, Routledge (Studies in Contemporary Music Andculture), 2002. 
Mimaroğlu, İlhan, Elektronik Müzik, Pan Yayınları, 1991.

Nougé, Paul, "Music is Dangerous", trans: Felix Giovanelli, View Magazine: Surrealism in Belgium, vol. VII, No:2, December 1946.

Pöğün Turgut,İlhan Usmanbaş'ın Müziğinde Görece Notalama, Perpetuum Mobile: İlhan Usmanbaş'ın Yapıtı, (Ed.) Aykut Köksal, (Ed.) Mehmet Nemutlu, (Ed.) Kıvılcım Yıldız Şenürkmez, Pan Yayıncılık, 2015, s.188-204.

Schaeffer, Pierre, In Search of A Concrete Music, University of California Press, 2012.

Slonimsky, Nicolas, "Surrealim and Music", Writings on Music: Music of the Modern Era, (Ed.) Electra Slonimsky Yourke, Routledge, 2005.

Stacey, Peter F., Boulez and Modern Concept, University of Nebraska Press, 1987.

Szekely, Michael, “Jazz Naked Fire Gesture: Improvisation as Surrealism”, Papers of Surrealism, Issue:9, Summer 2011.

Usmanbaş, İlhan, Müzik Dilinin Mantı̆̆ı, Felsefe ve Sanat Sempozyumu, (Ed.) Ömer Naci Soykan, Ara Yayınc1l1k, İstanbul, 1990, s. 149-154. 
